\title{
Relationships between Polarization and Openness in Korean Economy
}

\author{
Jinman $\mathrm{Yoo}^{1}$, Chao $\mathrm{Wu}^{1} \&$ Keunyeob $\mathrm{Oh}^{1}$ \\ ${ }^{1}$ Department of International Trade, Chungnam National University, Korea \\ Correspondence: Keunyeob Oh, Department of International Trade, Chungnam National University, Daejon City, \\ Korea. E-mail:kyoh@cnu.ac.kr
}

Received: April 4, $2015 \quad$ Accepted: June 29, $2015 \quad$ Online Published: August 18, 2015
$\begin{array}{ll}\text { doi:10.5539/ass.v11n24p79 } & \text { URL: http://dx.doi.org/10.5539/ass.v11n24p79 }\end{array}$

\begin{abstract}
International trade usually changes the production patterns of an economy. The share of exporting industries tends to increase and that of importing industries tends to decrease. In the process of industrial restructuring, it is natural for the economy to experience a concentration toward exporting industries. At the same time, this concentration might also occur within separate industries; exporting firms tend to grow and the share of other firms tends to decrease. All these changes can result in a polarization of the economy. This paper investigates if this polarization trend occurred in the Korean economy by using industry and firm level data. In particular, we explore the question of whether there is any relationship between polarization and international trade, as there has been a lot of criticism focused on the idea that international trade has resulted in income inequality and polarization of the Korean economy. We calculated the GINI coefficient and other indices to measure the degree of polarization, and we performed regression analysis on the time series and panel data. This paper finds that there is a positive relationship between export ratio and polarization.
\end{abstract}

Keyword: Korea, polarization, international trade, GINI

\section{Introduction}

It seems undeniable that the rapid growth of the Korean economy during the past 50 years was only possible because of the expansion of international trade, and exports were particularly important in this expansion. According to growth accounting, the economic growth is due to two factors: input growth and productivity growth. Trade with other countries was critical for both, and the Korean economy owes its success to international trade. But international trade has other economic side effects that are not as desirable. First, consider the income distribution problem. In particular, polarization in various areas can emerge in the context of international trade expansion. International trade gives rise to significant gains in the exporting industry, which can result in benefits for holders of capital resources, exporting companies and workers associated with these fields. The Heckscher Ohlin theory of international trade can give us some important ideas about who benefits and who loses in this situation. If the wealthy classes enjoy gains from international trade, undesirable income distribution effects will result. Second, the positive effects from exports have, of late, been decreasing in the Korean economy. It is unknown at present whether there is significant spillover from exports to other areas; for example, in 1990, exports of 1 billion KRW lead to the employment of 58.6 workers in 1990, but this had dropped to 12.6 workers by 2005 , and further to 7.7 workers by 2012. (Institute for International Trade, 2014)

This paper investigates the relationship between international trade and polarization. We will look at the relationship between international trade and industry using industry data from whole industries and individual firms. In particular, we calculate GINI-similar coefficients and other measures to obtain the polarization indices, and we perform regression analysis on the time series and panel data of these indices. This paper finds that there is a positive relationship between export and polarization.

There are several ways to define polarization; we consider it to be the gap in peoples' incomes, the gap between exporting industries and other industries, and the gap among firms in a particular industry. These gaps can be widened by international trade. First, the Heckscher-Ohlin theory of international trade states that, in the long run, free trade benefits the factors of production that are abundant and hurts factors of production that are scarce. Second, a gap between exporting industries and importing industries may exist in the short run. Third, within an industry, exporting companies will become larger while the other companies will become smaller. Fourth, if the exporting companies are large firms, the gap between large firms and small and medium sized firms will be 
larger. As a result, international trade will result in the polarization of the economy.

Even in many advanced countries, it has been reported that increased trade has negative income distribution effects. This paper uses trade data at the industry and firm levels, and investigates the effects of international trade on the polarization of the economy. This research is expected to determine whether the expansion of international trade in Korea widened the gap in the economy, and to identify the factors affecting polarization.

\section{Literature}

When we consider the relationship between economic growth and income inequality in developing countries, the effects of economy globalization should be investigated. Many empirical studies including Feenstra and Hanson (1997) have addressed this topic. Most of them have pointed to the increases in income differences caused by economic globalization (Sato \& Fukushige, 2007). An important study comes from Feenstra and Hanson (1997); they investigated the effects of Foreign Direct Investment (FDI) on the skilled labor share of wages in Mexico from 1975-1988. FDI was found to increase the demand for, and the wages of, skilled labor, and this effect was particularly large in FDI concentrated regions. Another example relates to U.S industry. Borjas and Ramsey (1995) argued that employment changes in trade concentrated industries can explain the inequality in the U.S. Hanson and Harrison (1999) analyzed the relationship between trade reform and rising wage inequality, focusing on the 1985 Mexican trade reform. Wage inequality in Mexico rose after the reform, which is puzzling in a Heckscher-Ohlin context if we assume that Mexico has a comparative advantage in producing low skill-intensive goods.

More recently, Lim and McNelis (2014) examined the relationship between the Gini coefficient, trade-openness, aid, and FDI flows. Panel data estimates are provided for the overall data set (42 low to middle income countries). It finds empirically that trade openness is more able to change income inequality than either FDI or foreign aid, but that its effectiveness depends on the stage of development. The countries with high labor intensity in production and greater openness generate lower inequality in response to favorable shocks to export demand and trade.

Many papers have attempted to address this question by using data for the Korean economy, but the results are not consistent. For example, even within a single paper we find mixed results. Mah $(2002,2003)$ studied the impact of changes in trade values and FDI inflows on the Gini coefficients for Korea. Mah (2002) found that Gini coefficients tend to increase with trade liberalization measures and FDI inflows, and concluded that the progress of globalization caused income inequality to deteriorate in Korea, which supports the Feenstra-Hanson (1997) hypothesis. On the other hand, Mah's regression results indicated that neither changes in the openness ratios, regardless of the measures, nor those in the FDI inflows were significant in influencing the Gini coefficients. Sato and Fukushige (2009) analyzed the determinants of the Gini coefficient for income and expenditure for the Korean economy. Their results suggest that the effect of economic globalization has two routes, and two different speeds, in affecting income inequality. Recently, Kang (2014) examined the relationship between globalization and income distribution in Korea (Note 1).

The study investigates the effects of trade openness, inward and outward FDI flows, and per capita GDP on income distribution from 1992 to 2011. It found that, as trade openness and per capita GDP increased, income inequality was reduced. Meanwhile, income equality deteriorates as inward and outward FDI flows increase. The negative effect of inward FDI flows on income inequality is greater than that of outward FDI flows.

This paper differs from those mentioned above in the sense that we do not focus on the relationship between international trade and income inequality, but on the relationship between polarization and international trade. Here, we use concentration as a proxy for polarization; namely, the concentration of industries and the concentration of firms. Thus, we will use concentration indices like HH (Hirschman-Herfindahl) and Gini coefficients. The Gini coefficients used in this paper are not used to indicate income distribution. We report how much concentration occurs among industries and firms, and we explore the effects of international trade on this concentration or polarization. This research, therefore, uses production data instead of wage data or per capita income data, making it relatively unique.

\section{Changes in Industry Structure}

The industry structure of the Korean economy has changed from primary industries such as agriculture and fisheries, to secondary industries such as automobiles and semi-conductors over the past few decades. By using OECD STAN data (rev.3) we obtained the following results (Note 2). 


\subsection{Changes in Industry Structure}

Table 1. Industry shares

\begin{tabular}{cccccccccc}
\hline & 1970 & 1975 & 1980 & 1985 & 1990 & 1995 & 2000 & 2005 & 2009 \\
\hline Agriculture and fishery $^{*}$ & 0.291 & 0.269 & 0.160 & 0.133 & 0.087 & 0.062 & 0.046 & 0.033 & 0.026 \\
Mining and Manufacturing $^{* *}$ & 0.215 & 0.248 & 0.280 & 0.311 & 0.298 & 0.297 & 0.315 & 0.304 & 0.301 \\
Service $^{* * *}$ & 0.494 & 0.483 & 0.560 & 0.557 & 0.615 & 0.642 & 0.639 & 0.663 & 0.673 \\
\hline
\end{tabular}

* ISIC(International Standard Industry Classification) C01-C05

** ISIC C10-C37

*** ISIC C40-C99

These numbers are shown in Table 1. In Korea, primary industry (agriculture and fishery) has been reduced to less than $3 \%$, from $30 \%$ during the last four decades, while secondary industry (mining and manufacturing) grew from $20 \%$ to $30 \%$. The service sector is almost $70 \%$, and has increased from $50 \%$ in 1970 .

\subsection{Industry Structure Change in Manufacturing}

Even within manufacturing, the Korean economy has experienced dynamic changes in industry structure (Table 2).

Table 2. Changes in industry structure inside manufacturing

\begin{tabular}{|c|c|c|c|c|c|c|c|c|c|}
\hline & 1970 & 1975 & 1980 & 1985 & 1990 & 1995 & 2000 & 2005 & 2009 \\
\hline Food products, beverages and tobacco & 0.196 & 0.131 & 0.108 & 0.091 & 0.073 & 0.064 & 0.062 & 0.052 & 0.051 \\
\hline Textiles, textile products, leather and footwear & 0.280 & 0.264 & 0.233 & 0.186 & 0.133 & 0.087 & 0.082 & 0.051 & 0.041 \\
\hline Wood and products of wood and cork & 0.030 & 0.020 & 0.008 & 0.008 & 0.008 & 0.008 & 0.006 & 0.005 & 0.004 \\
\hline Pulp, paper, paper products, printing and publishing & 0.059 & 0.054 & 0.038 & 0.052 & 0.053 & 0.062 & 0.048 & 0.041 & 0.041 \\
\hline Chemical, rubber, plastics and fuel products & 0.142 & 0.170 & 0.199 & 0.167 & 0.144 & 0.162 & 0.151 & 0.170 & 0.155 \\
\hline Other non-metallic mineral products & 0.063 & 0.063 & 0.065 & 0.063 & 0.066 & 0.051 & 0.041 & 0.035 & 0.038 \\
\hline Basic metals and fabricated metal products & 0.027 & 0.051 & 0.102 & 0.129 & 0.138 & 0.138 & 0.126 & 0.165 & 0.142 \\
\hline Machinery and equipment & 0.081 & 0.132 & 0.166 & 0.179 & 0.235 & 0.275 & 0.337 & 0.330 & 0.338 \\
\hline Transport equipment & 0.085 & 0.085 & 0.052 & 0.092 & 0.117 & 0.127 & 0.123 & 0.135 & 0.175 \\
\hline Manufacturing n.e.c. and recycling & 0.037 & 0.031 & 0.029 & 0.033 & 0.032 & 0.025 & 0.023 & 0.016 & 0.014 \\
\hline
\end{tabular}

* Manufacturing is from ISIC C15-37.

From the table, we see a reduction in food products, beverages and tobacco, textiles, textile products, leather and footwear, wood and products of wood, and cork, while basic metals and fabricated metal products, machinery and equipment, and transport equipment have been steadily increasing.

\subsection{Industry Change in Terms of Technology Level}

It is generally acknowledged that the Korean economy has moved toward capital and technology intensive industries. In particular, we can observe that, as the Korean Economy has grown, it has moved toward high tech industries, from low tech industries. According to the classification by OECD, we can confirm the trend change. Table 3 shows those findings.

Table 3. Changes toward high technology industries

\begin{tabular}{ccccccc}
\hline & 1985 & 1990 & 1995 & 2000 & 2005 & 2009 \\
\hline HI & 0.120 & 0.157 & 0.191 & 0.234 & 0.227 & - \\
MH & 0.208 & 0.268 & 0.284 & 0.273 & 0.287 & - \\
ML & 0.302 & 0.275 & 0.279 & 0.271 & 0.321 & 0.295 \\
LO & 0.370 & 0.301 & 0.247 & 0.222 & 0.165 & 0.142 \\
H\&MH & 0.328 & 0.424 & 0.475 & 0.507 & 0.514 & 0.562 \\
\hline
\end{tabular}

* H, M, LO stand for High, Middle, Low technology, respectively. In the case of 2009, OECD did not provide for the $\mathrm{HI}$ and $\mathrm{MH}$ separately. 
In the table, HI, MH, ML, LO stand for high, mid high, mid low, and low, respectively. The Korean economy has been rapidly transformed from low and mid-low technology industries, to mid-high and high technology industries (Note 3).

\subsection{The Ratio of International Trade to GDP}

As is well known, the Korean economy depends heavily on international trade. The degree of dependence of the Korean economy on foreign trade has been increasing since the opening of the economy in the 1970s and, during this time, the growth strategy of the Korean economy was export-oriented. The ratio of international trade to GDP, which is sometimes referred to as openness, has recently been around $100 \%$. Figure 1 shows the trend of this ratio.

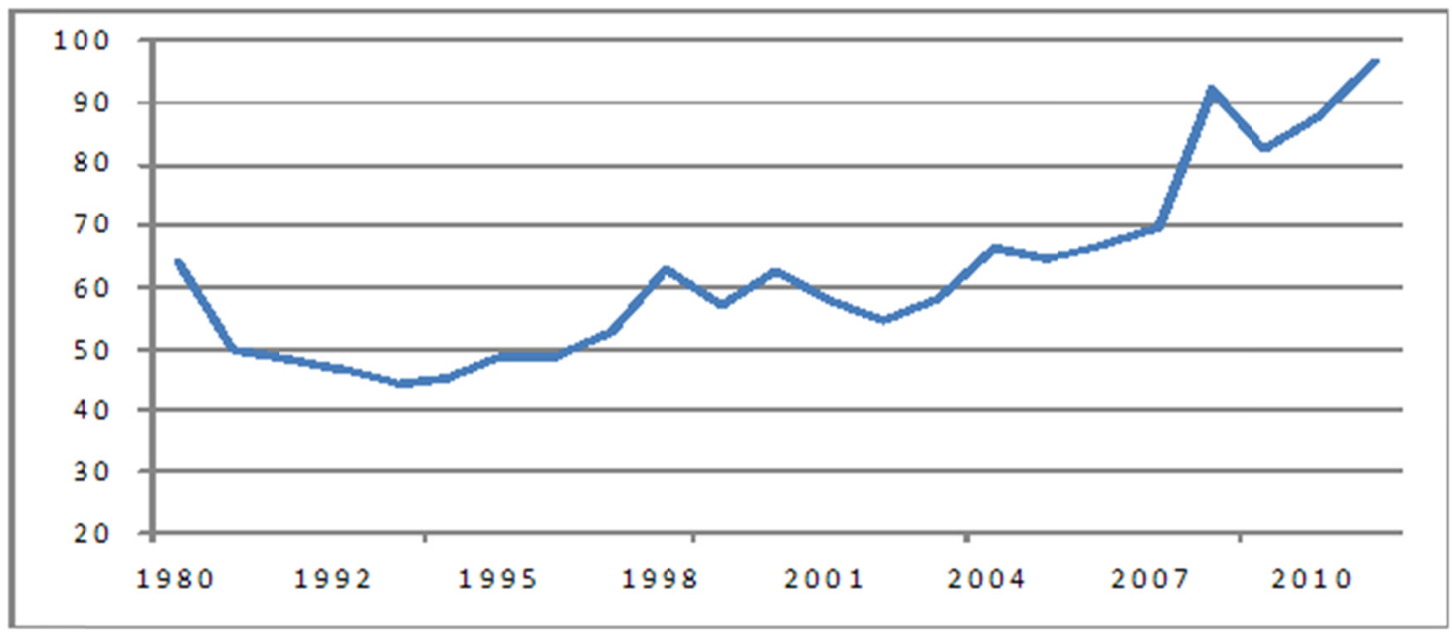

Source: KOSIS and Bank of Korea

Figure 1. Ratio of trade to GDP

This ratio rose rapidly in the 1970s (not shown in the figure) (Jang, 1999). After a period of slow change and decrease in the 1980s, the ratio began increasing again, and has continued ever since. Of interest is the fact that the trend of these ratios looks similar to the degree of concentration in the manufacturing industry. We anticipate finding similar patterns as we continue our research and calculations.

\section{Polarization of Production and International Trade}

International trade in the Korean economy has been increasing rapidly since the 1970s and the total amount of international trade has recently exceeded one trillion dollars. On the one hand, it would not be an exaggeration to say that international trade has made the economy grow and that the Korean people enjoy today's income level. On the other hand, it would be fair to say that international trade may have caused some amount of polarization within the economy.

During the decades of economic development, Korea experienced drastic changes in industry structure. The percentage share of manufacturing increased significantly. In addition, there were big changes, even within the manufacturing industry. All these changes seem to be related to international trade. Naturally, exporting industries have grown and importing industries have shrunk. These changes might result in the polarization of industries. In this section, we report on the degree of polarization by using manufacturing industry data.

\subsection{Measures}

We are going to use the degree of concentration as the proxy for the polarization index. In particular, we borrow some measures from other areas of economics, such as CR3 (concentration ratio 3), CR5, H-H (Hirschman-Herfindahl) index, and GINI (Gini's coefficients). For example, if we consider the polarization in an industry with $n$ firms, CR3 and CR5 are the share of the top three or five firms, and H-H is the sum of squares of each of the firms in the industry; $\mathrm{HH}=\sum \mathrm{s}_{\mathrm{i}}{ }^{2}$, where $\mathrm{s}_{\mathrm{i}}$ indicates the share of i-th firm. Gini was originally proposed to be a measure of income inequality, and is the most commonly used measure of inequality. A Gini coefficient of zero expresses perfect equality, that is, all values are the same. For the calculation, the following formula is used (Jasso, 1979): 


$$
G=\frac{1}{2 \mu n^{2}} \sum_{i=1}^{n} \sum_{j=1}^{n}\left|y_{i}-y_{j}\right|
$$

Where $\mathrm{y}_{\mathrm{i}(\mathrm{j})}$ indicates the sales of a firm $\mathrm{i}(\mathrm{j})$ and $\mu$ is the average of the sales, and $n$ is the number of firms. Usually, GINI is calculated based on i-th percentile of the population, but in this paper the number of firms does not equal one hundred; therefore, we use a GINI-similar (GINI-s) instead of GINI itself (Note 4). Therefore, the absolute size of GINI-s could be quite different from the usual GINI, and we should note that only the trend or the 'change' itself is meaningful. If we want to obtain the degree of concentration toward a few industries in the whole economy, $i(j)$ can indicate an industry. By the same token, the degree of concentration of an industry can indicate how the industry is concentrated toward some firms if we use $\mathrm{i}(\mathrm{j})$ for the firms in the industry.

\subsection{Industry Production}

First, we report CR3, CR5, H-H, GINI-s for 26 manufacturing industries in the Korean economy in Figure 2.

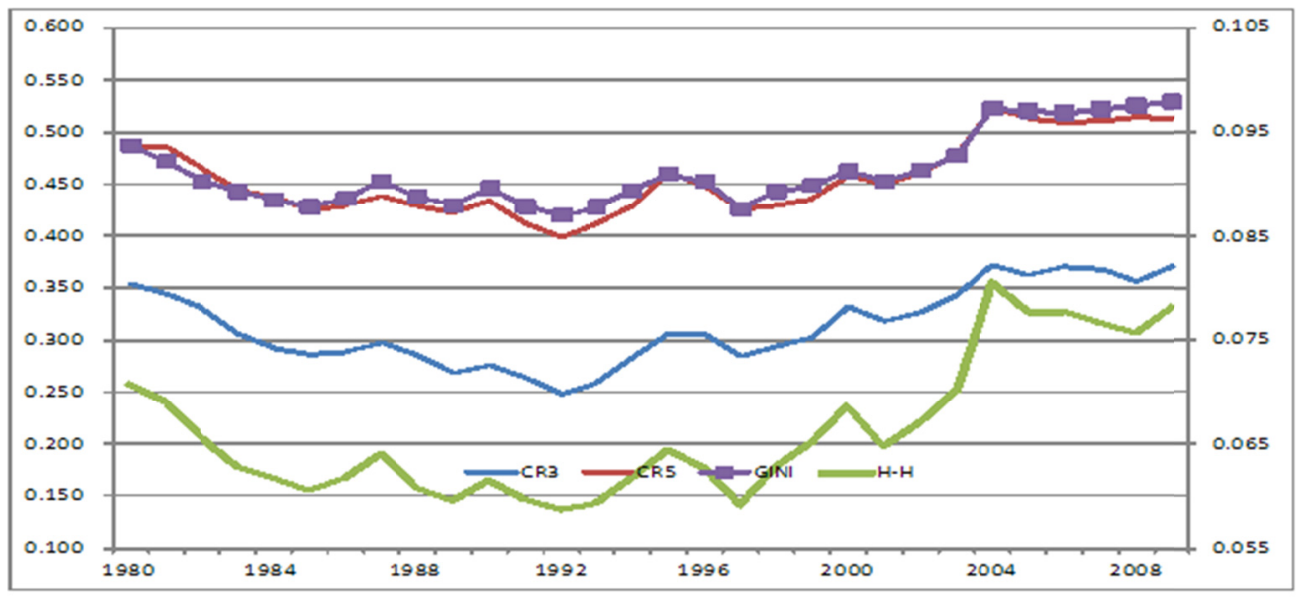

Figure 2. Trend of polarization of 26 industries

* Right hand side axis shows HH while CR3, CR5, GINI-s are expressed by left hand side axis.

All the indices have very similar shapes; four indices had a decreasing trend in the early 1990s and then increasing trends after the mid-90s. It seems that the manufacturing sector was dispersed in the 1990s, but began to focus on some specific sectors in the 2000 s, meaning that polarization mainly occurred in the mid and late 2000s. It is a relief to see that this increasing tendency has not continued in more recent years.

\subsection{International Trade}

The structure of international trade has changed greatly in Korea, and the change occurred along with the polarization of the economy; most exports and imports centered on a few items. We report the calculated results from the concentration indices in order to see the polarization trends. In the year 2009, the five largest exporting industries were ship building, semi-conductors, mobile phones, display panels, and motor vehicles, and these five items account for $43.5 \%$ of total exports. This shows that Korea's export economy is concentrated on only a few industries. By the seventies, light industries such as textiles and shoes were major exporting items, but high-tech and capital intensive items have been the main exports since the 1980s.

In the 2000s, another important phenomenon was that exports changed from being mostly final goods, to being mostly intermediate goods. The share of parts, components, and half-finished goods being exported has been growing a lot recently due to the increase in the production of final goods overseas. Nowadays, intermediate goods are produced in foreign countries with final goods as manufacturing factories moved abroad. Due to this trend, the export market of Korean products is transferring from advanced countries to developing countries where manufacturing factories are located. As this has been happening, Korean exports have been concentrating on a few items like shipbuilding, IT (semi-conductor, flat display panel, mobile phones), and cars. In particular, exports of display panels have risen sharply since the mid-2000s when the export of the LCD panel for TVs began.

For an understanding of the background to this we report the degree of concentration of export items by using UN Comtrade data. From SITC 3 digit data with 'rev.2', we used 255 sub industries and calculated the 
concentrations. About 230 out of 255 industries have reported exports. The GINI-s in figure 3 show that the concentration of the Korean export economy has been increasing since the mid-1990s.

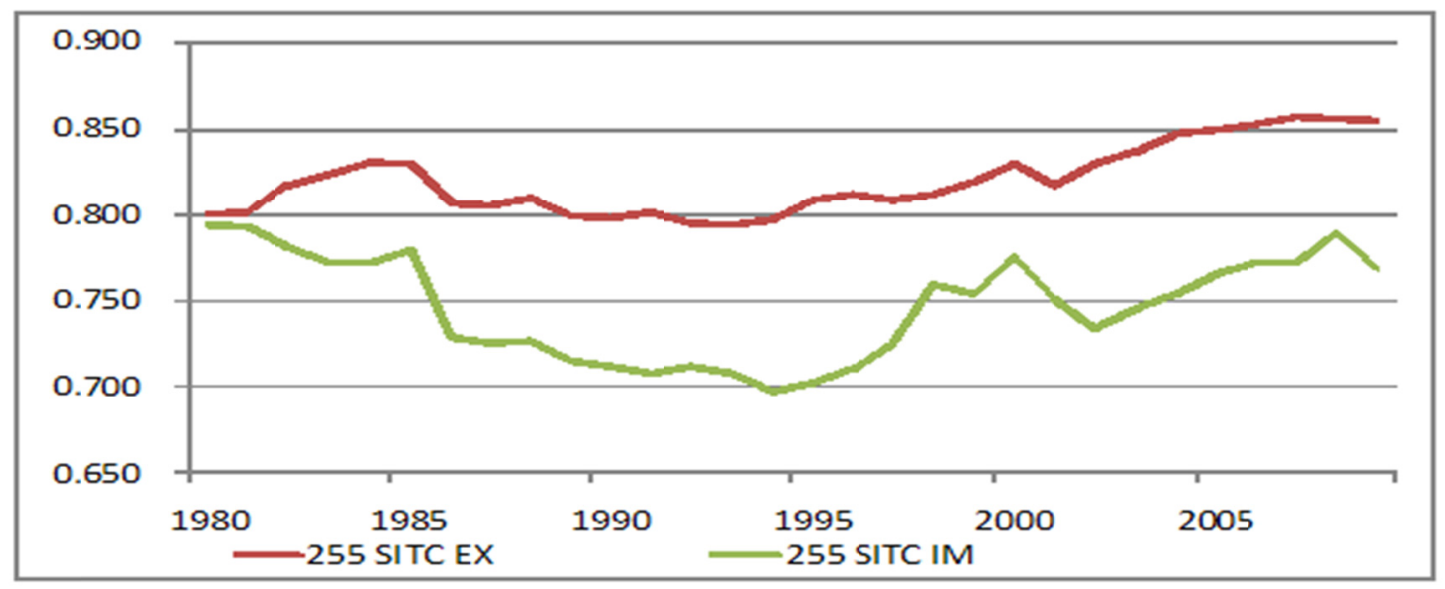

Figure 3. Concentration of trade in the Korean economy: Data from 255 sub industries

In Figure 3, two lines are shown. If the GINI-s is a large number, it means that the exports and imports are centered on only a few items (Note 5). Basically, it seems that Korean economy exports are more concentrated than Korean economy imports, but both lines have been increasing in recent years.

Interestingly, we find a similar U-shape for both industrial products and international trade. It seems that the production concentration is positively correlated with international trade concentration. In addition, these U-shapes look to be related to the degree of dependence on foreign trade, shown in Figure 2.

\subsection{Trade Partners}

What about Korea's trading partners? Was the concentration tendency related to exporting or importing countries? We report two indices that indicate the degree of concentration of trading partners. All the data are from Comtrade Data of UN.

One distinct characteristic is that Korea's exports and imports have been concentrating on a few countries, and five countries account for more than 50\%. In past years, Korea has exported the most to the US and then to Japan. In the 2000s, however, Korea exported the most goods to China, with the US and Japan ranking second and third, respectively. As for importing partners, in the 2000s Korea imported the largest amount from Japan, with the US in second place, but now China is the number one source of imports into Korea.

Figure 4 shows CR5 (concentration ratio 5) and CR10, which indicate the share of the top five or ten trading partners. Even though those numbers are still relatively large, we see a decreasing tendency in concentration, which means that Korea's efforts to diversify trading partners have been successful. Such a tendency can also be found from the $\mathrm{HH}$ index in the figure.
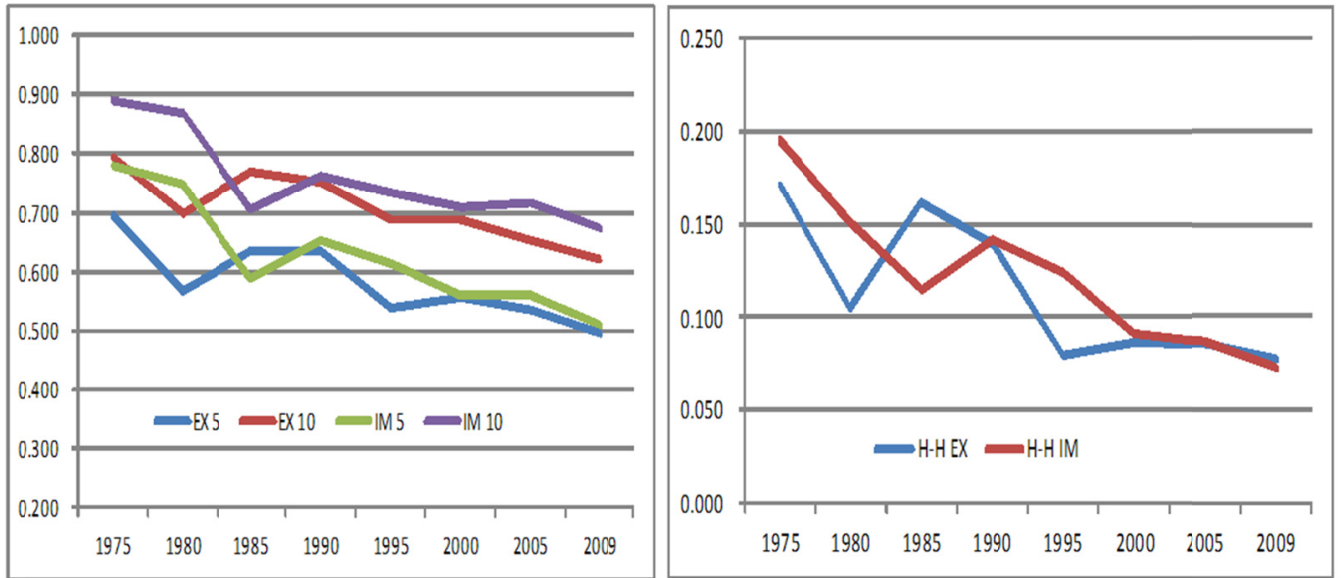

Figure 4. CR5, CR10, and H-H's of trade partners 


\section{A Regression of Trade and Production: Firm Level Data}

In this section, we analyze the polarization of production and international trade by using firm level manufacturing data from 1985-2013. We use the Kisvalue data provided by Korea Investors Service Inc. The Kisvalue database contains data from almost 20,000 firms, of which 10,756 firms operate in 23 manufacturing industries. We selected 2,018 firms from this number that were consecutively included in the dataset for 29 years. We summed the firm level data to get production and trade data at the industry level. Thus, the data are different from the results above, which were obtained from industry level, UN Comtrade and STAN data.

Two types of GINI-s were calculated from the data. One is GINI-s for a particular industry in a specific year using data from an individual firm. From this we obtained $23 * 29$ panel data (Appendix Table 2). The other is 29 time series GINI-s using the industry data, which was calculated from firm level data. This GINI-s might show the degree of concentration among the industries for a particular year. Figure 5 shows the second GINI-s (The numbers are shown in the last column of Appendix Table 2). These figures, calculated from the firm level data, seem to be similar to Figures 2 and 3, which were calculated using industry level data. Since the data source is not the same as before, these figures do not necessarily have to be exactly the same as the previous ones, but the basic trends look similar in recent years: concentration and polarization are increasing in Korean manufacturing.

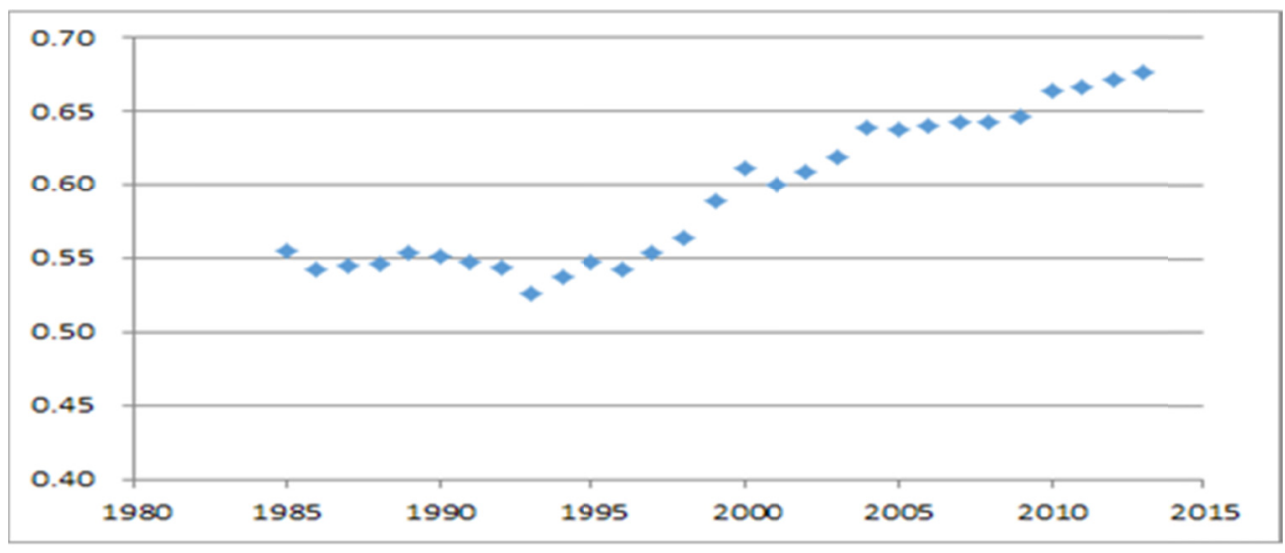

Figure 5. Increasing trend of GINI-s by using firm level data

Now we report the results from regression analyses to see the relationship between the GINI-s and the trade dependence ratio.

First, Table 4 indicates the results for the time series data of the manufacturing industry as a whole. The number of data, 29, indicates 29 years. We used a robust standard errors estimation by using the sandwich estimator of variance. The dependent variable is GINI-s, and the independent variable is the ratio of exports to total production in each year. We summed up the total amount of exports and production of the firms in the data set. The regression results show that the export ratio is significant at the $10 \%$ significance level when we use the usual standard errors, and significant at $1 \%$ when we use the robust errors. In all, it seems reasonable to conclude that the export ratio has a positive relationship with GINI-s.

Table 4. Exports and Polarization in time series data

\begin{tabular}{llllll}
\hline & Coef. & Std. Err. & t-value & Robust Std. Err. & $\mathrm{t}$ \\
\hline Export Ratio & 0.162 & 0.093 & 1.80 & 0.060 & 2.72 \\
constant & 0.563 & 0.019 & 29.13 & 0.015 & 37.11 \\
$\mathrm{R}^{2}$ & 0.1070 & & & & \\
$\mathrm{n}$ & 29 & & & & \\
\hline
\end{tabular}

Second, we report the regression result by using the panel data: GINI-s in each industry for every year. Several panel data regression models are used: fixed effect model, random effect model, two-way effects model, and two-way GLS model. The two way GLS model was used in order to consider the heterogeneity of the error terms in the panel data. Here, we also find a positive relationship between the export ratio and polarization. When the export ratio is large in an industry, the GINI-s also tends to be large. 
Table 5. Exports and Polarization in panel data (Note 6)

\begin{tabular}{lllll}
\hline & Fixed Effect & Random Effect & Two-Way Effect & Two-Way GLS \\
\hline export rate & $0.023(1.57)$ & $0.025^{*}(1.68)$ & $0.048^{* * *}(3.25)$ & $0.029^{* * *}(2.98)$ \\
constant & $0.627^{* * *}(239.84)$ & $0.626^{* * *}(21.9)$ & $0.567^{* * *}(66.3)$ & $0.598^{* * *}(100.3)$ \\
$\mathrm{R}^{2}$ & 0.2075 & 0.2075 & 0.2075 & \\
$\mathrm{n}$ & 667 & 667 & 667 & 667 \\
\hline
\end{tabular}

${ }^{*} \mathrm{p}<.1 ;{ }^{* *} \mathrm{p}<.05 ;{ }^{* * *} \mathrm{p}<.01$, the numbers in parenthesis are t-values.

\section{Conclusion}

International trade usually changes the production patterns of an economy; the share of exporting industries tends to increase while the share of importing industries tends to decrease. Thus, it is natural for an economy to experience concentration in export-centric industries. This concentration might also occur within individual industries; the exporting firms tend to grow, and the share of other firms tends to decrease. All these changes can result in polarization of the economy. This paper investigates if a polarization trend exists in the Korean economy by using industry level and firm level data.

In addition, we explore the relationship between polarization and international trade. Since much criticism has been focused on the idea that international trade has resulted in polarization and income inequality in the Korean economy, this paper tries to determine the effects of international trade on polarization. We borrowed an index that is similar to the GINI coefficient and other indices to measure the degree of polarization, and performed regression analysis with this index, and the export ratio. Time series and panel data were used. We find that there is a positive relationship between export ratio and polarization, which indicates that international trade or openness may lead to polarization in the Korean economy.

\section{Acknowledgments}

This work was supported by the National Research Foundation of Korea Grant funded by the Korean Government (NRF-2013S1A5A2A01018135)

\section{References}

Attanasio, O., Goldberg, P., \& Pavenik, N. (2003). Trade Reforms and Wage Inequality in Columbia. Journal of Development Economics, 74, 331-366. http://dx.doi.org/10.1016/j.jdeveco.2003.07.001

Beyer, H., Rojas, P., \& Vergara, R. (1999). Trade liberalization and wage inequality. Journal of Development Economics, 59(1), 103-123. http://dx.doi.org/10.1016/S0304-3878(99)00007-3

Borjas, G., \& Ramey, V. (1995). Foreign Competition, Market Power, and Wage Inequality. Quarterly Journal of Economics, 110(4), 1075-1110. (November). http://dx.doi.org/10.2307/2946649

De Locker, J. (2007). Do Exports Generate Higher Productivity? Evidence from Slovenia. Journal of International Economics, 73, 69-98. http://dx.doi.org/10.1016/j.jinteco.2007.03.003

Feenstra, R. C., \& Hanson, G. (1997). Foreign Direct Investment and Relative Wage: Evidence from Mexico's Maquiladoras. Journal of International Economics, 42, 371-393. http://dx.doi.org/10.1016/S0022-19 96(96)01475-4

Galian, S., \& Sanguinetti, P. (2003). The Impact of Trade Liberalization on Wage Inequality: Evidence from Argentina. Journal of Development Economics, 72(2), 497-513. http://dx.doi.org/10.1016/S0304-3878 (03)00117-2

Gini, C. (1936). On the Measure of Concentration with Special Reference to Income and Statistics. Colorado College Publication, General Series No. 208, 73-79.

Hanson, G., \& Harrison, A. (1999). Trade and Wage Inequality in Mexico. Industrial and Labor Relations Review, 52, 271-288. Retrieved from http://www.researchgate.net/profile/Ann_Harrison/publication/ 5119362_Trade_liberalization_and_wage_inequality_in_Mexico/links/0deec52bc925257959000000.pdf

Harris, R. (2002). Foreign Ownership and Productivity in the United Kingdom-Some Issues When Using the ARD Establishment Level Data. Scottish Journal of Political Economy, 49, 318-335. http://dx.doi.org/10.1111/1467-9485.00234

Harrison, A., \& Hanson, G. (1999). Who gains from trade reform? Some remaining puzzles. Journal of Development Economics, 59, 125-154. http://dx.doi.org/10.1016/S0304-3878(99)00008-5 
Institute for International Trade. (2014). Trade Brief.

Jang, K. (1998). The effects of openness on the economic growth and inflation. Economic Analysis, Bank of Korea, 4(1).

Jasso, G. (1979). On Gini's Mean Difference and Gini's Index of Concentration. American Sociological Review, 44(5), 867-870. Retrieved from http://www.jstor.org/stable/2094535?seq =1\#page_scan_tab_contents

Kang, M. (2014). The Study on the Effect of Trade Openness and FDI on Income Distribution. International Commerce and Information Review, 16(4), 151-167. Retrieved from http://www.dbpia.co.kr/ Journal/ArticleDetail/3540173

Lim, G. C., \& McNelis, P. D. (2014). Income Inequality, Trade and Financial Openness, RES_SPR Conference on Macroeconomic Challenges Facing Low-Income Countries, IMF. Retrieved from http://www.imf.org/external/np/seminars/eng/2014/lic/pdf/Lim.pdf

Hamilton, L. C. (2013). Statistics with Stata: Version 12 (8th ed.). Cengage.

Mah, J. S. (2003). A Note on Globalization and Income Distribution: The Case of Korea: 1975-1995. Journal of Asian Economics, 14(1), 157-164. http://dx.doi.org/10.1016/S1049-0078(02)00244-0

Mah, J. S. (2002). The Impact of Globalization on Income Distribution: The Korean Experience. Applied Economic Letters, 9(15), 1007-1009. http://dx.doi.org/10.1080/13504850210149124

Milanovic, B., \& Squire, L. (2005). Does Tariff Liberalization Increase Wage Inequality? Some Empirical Evidence, NBER Working Paper, No.11046. Retrieved from https://ideas.repec.org/p/nbr/nberwo/11046.html

OECD. (2011). Retrieved from http://www.oecd.org/sti/ind/48350231.pdf

Sato, S., \& Fukushige, M. (2009). Globalization and Economic Inequality in the Short and Long Run: The Case of South Korea 1975-1995. Journal of Asian Economics, 20(1), 62-68. http://dx.doi.org/10.1016/j.asieco. 2008.07.002

\section{Appendix}

Table 1. Industry classification in Korea

\begin{tabular}{|c|c|c|}
\hline KSIC2 & Manufacturing & $\begin{array}{l}\text { OECD classification } \\
\text { by tech level }\end{array}$ \\
\hline $\mathrm{C} 10$ & Manufacture of Food Products & $\mathrm{L}$ \\
\hline $\mathrm{C} 11$ & Manufacture of Beverages & $\mathrm{L}$ \\
\hline $\mathrm{C} 12$ & Manufacture of Tobacco Products & $\mathrm{L}$ \\
\hline $\mathrm{C} 13$ & Manufacture of Textiles, Except Apparel & $\mathrm{L}$ \\
\hline $\mathrm{C} 14$ & Manufacture of wearing apparel, Clothing Accessories and Fur Articles & $\mathrm{L}$ \\
\hline $\mathrm{C} 15$ & Tanning and Dressing of Leather, Manufacture of Luggage and Footwear & $\mathrm{L}$ \\
\hline $\mathrm{C} 16$ & Manufacture of Wood Products of Wood and Cork; Except Furniture & $\mathrm{L}$ \\
\hline $\mathrm{C} 17$ & Manufacture of Pulp, Paper and Paper Products & $\mathrm{L}$ \\
\hline $\mathrm{C} 18$ & Printing and Reproduction of Recorded Media & $\mathrm{L}$ \\
\hline C19 & $\begin{array}{l}\text { Manufacture of Coke, hard-coal and lignite fuel briquettes and Refined Petroleum } \\
\text { Products }\end{array}$ & ML \\
\hline $\mathrm{C} 20$ & $\begin{array}{l}\text { Manufacture of chemicals and chemical products except pharmaceuticals, medicinal } \\
\text { chemicals }\end{array}$ & $\mathrm{MH}$ \\
\hline $\mathrm{C} 21$ & Manufacture of Pharmaceuticals, Medicinal Chemicals and Botanical Products & $\mathrm{H}$ \\
\hline $\mathrm{C} 22$ & Manufacture of Rubber and Plastic Products & ML \\
\hline $\mathrm{C} 23$ & Manufacture of Other Non-metallic Mineral Products & ML \\
\hline $\mathrm{C} 24$ & Manufacture of Basic Metal Products & ML \\
\hline $\mathrm{C} 25$ & Manufacture of Fabricated Metal Products, Except Machinery and Furniture & ML \\
\hline $\mathrm{C} 26$ & $\begin{array}{l}\text { Manufacture of Electronic Components, Computer, Radio, Television and Communication } \\
\text { Equipment \& Apparatuses }\end{array}$ & $\mathrm{H}$ \\
\hline
\end{tabular}




\begin{tabular}{llc}
\hline C27 & Manufacture of Medical, Precision and Optical Instruments, Watches and Clocks & $\mathrm{H}$ \\
C28 & Manufacture of electrical equipment & $\mathrm{MH}$ \\
C29 & Manufacture of Other Machinery and Equipment & $\mathrm{MH}$ \\
C30 & Manufacture of Motor Vehicles, Trailers and Semitrailers & $\mathrm{MH}$ \\
C31 & Manufacture of Other Transport Equipment & $\mathrm{MH}$ \\
C32 & Manufacture of Furniture & $\mathrm{L}$ \\
C33 & Other manufacturing & $\mathrm{L}$ \\
\hline
\end{tabular}

Table 2. GINI-s by industries and by years

\begin{tabular}{|c|c|c|c|c|c|c|c|c|c|c|c|c|}
\hline KSIC & $\mathrm{C} 10$ & $\mathrm{C} 11$ & $\mathrm{C} 13$ & $\mathrm{C} 14$ & $\mathrm{C} 15$ & $\mathrm{C} 16$ & $\mathrm{C} 17$ & $\mathrm{C} 18$ & C19 & $\mathrm{C} 20$ & $\mathrm{C} 21$ & $\mathrm{C} 22$ \\
\hline 1985 & 0.55 & 0.52 & 0.64 & 0.47 & 0.26 & 0.12 & 0.53 & 0.30 & 0.80 & 0.68 & 0.58 & 0.47 \\
\hline 1986 & 0.56 & 0.54 & 0.65 & 0.50 & 0.37 & 0.33 & 0.53 & 0.32 & 0.82 & 0.68 & 0.59 & 0.55 \\
\hline 1987 & 0.59 & 0.59 & 0.67 & 0.51 & 0.35 & 0.40 & 0.55 & 0.31 & 0.82 & 0.69 & 0.60 & 0.50 \\
\hline 1988 & 0.59 & 0.57 & 0.68 & 0.49 & 0.41 & 0.49 & 0.57 & 0.23 & 0.81 & 0.71 & 0.58 & 0.53 \\
\hline 1989 & 0.60 & 0.59 & 0.67 & 0.50 & 0.45 & 0.48 & 0.58 & 0.24 & 0.79 & 0.71 & 0.56 & 0.52 \\
\hline 1990 & 0.62 & 0.61 & 0.65 & 0.52 & 0.45 & 0.39 & 0.58 & 0.28 & 0.80 & 0.71 & 0.59 & 0.51 \\
\hline 1991 & 0.64 & 0.62 & 0.65 & 0.54 & 0.46 & 0.53 & 0.59 & 0.30 & 0.81 & 0.71 & 0.58 & 0.53 \\
\hline 1992 & 0.64 & 0.63 & 0.65 & 0.54 & 0.47 & 0.52 & 0.61 & 0.35 & 0.81 & 0.71 & 0.57 & 0.54 \\
\hline 1993 & 0.64 & 0.63 & 0.63 & 0.54 & 0.50 & 0.44 & 0.61 & 0.30 & 0.80 & 0.68 & 0.56 & 0.54 \\
\hline 1994 & 0.64 & 0.66 & 0.64 & 0.59 & 0.49 & 0.49 & 0.63 & 0.31 & 0.81 & 0.71 & 0.56 & 0.52 \\
\hline 1995 & 0.65 & 0.67 & 0.63 & 0.60 & 0.51 & 0.46 & 0.65 & 0.31 & 0.81 & 0.73 & 0.55 & 0.51 \\
\hline 1996 & 0.64 & 0.64 & 0.62 & 0.60 & 0.52 & 0.47 & 0.66 & 0.32 & 0.80 & 0.73 & 0.54 & 0.51 \\
\hline 1997 & 0.64 & 0.64 & 0.60 & 0.62 & 0.49 & 0.50 & 0.66 & 0.34 & 0.83 & 0.73 & 0.55 & 0.53 \\
\hline 1998 & 0.66 & 0.61 & 0.60 & 0.55 & 0.46 & 0.52 & 0.65 & 0.36 & 0.83 & 0.74 & 0.56 & 0.56 \\
\hline 1999 & 0.66 & 0.61 & 0.59 & 0.52 & 0.50 & 0.53 & 0.62 & 0.36 & 0.82 & 0.75 & 0.54 & 0.54 \\
\hline 2000 & 0.66 & 0.67 & 0.57 & 0.52 & 0.48 & 0.51 & 0.64 & 0.34 & 0.81 & 0.76 & 0.54 & 0.54 \\
\hline 2001 & 0.65 & 0.67 & 0.57 & 0.52 & 0.49 & 0.52 & 0.64 & 0.35 & 0.81 & 0.76 & 0.54 & 0.53 \\
\hline 2002 & 0.66 & 0.67 & 0.55 & 0.52 & 0.47 & 0.52 & 0.65 & 0.34 & 0.82 & 0.75 & 0.54 & 0.52 \\
\hline 2003 & 0.67 & 0.68 & 0.57 & 0.51 & 0.49 & 0.51 & 0.64 & 0.32 & 0.83 & 0.75 & 0.54 & 0.49 \\
\hline 2004 & 0.66 & 0.63 & 0.56 & 0.51 & 0.49 & 0.53 & 0.64 & 0.32 & 0.83 & 0.77 & 0.55 & 0.50 \\
\hline 2005 & 0.66 & 0.65 & 0.58 & 0.51 & 0.48 & 0.52 & 0.64 & 0.29 & 0.83 & 0.77 & 0.55 & 0.54 \\
\hline 2006 & 0.67 & 0.64 & 0.58 & 0.53 & 0.47 & 0.50 & 0.63 & 0.32 & 0.83 & 0.77 & 0.55 & 0.55 \\
\hline 2007 & 0.67 & 0.63 & 0.59 & 0.53 & 0.47 & 0.47 & 0.63 & 0.34 & 0.83 & 0.78 & 0.56 & 0.55 \\
\hline 2008 & 0.65 & 0.62 & 0.59 & 0.55 & 0.47 & 0.51 & 0.64 & 0.35 & 0.83 & 0.79 & 0.56 & 0.56 \\
\hline 2009 & 0.65 & 0.63 & 0.60 & 0.55 & 0.47 & 0.51 & 0.65 & 0.39 & 0.83 & 0.79 & 0.56 & 0.58 \\
\hline 2010 & 0.65 & 0.64 & 0.63 & 0.55 & 0.50 & 0.50 & 0.63 & 0.38 & 0.83 & 0.80 & 0.55 & 0.57 \\
\hline 2011 & 0.65 & 0.68 & 0.60 & 0.55 & 0.52 & 0.51 & 0.62 & 0.41 & 0.83 & 0.80 & 0.55 & 0.58 \\
\hline 2012 & 0.65 & 0.72 & 0.61 & 0.56 & 0.53 & 0.53 & 0.63 & 0.43 & 0.83 & 0.80 & 0.53 & 0.59 \\
\hline 2013 & 0.65 & 0.72 & 0.61 & 0.57 & 0.56 & 0.48 & 0.63 & 0.41 & 0.83 & 0.80 & 0.54 & 0.59 \\
\hline KSIC & $\mathrm{C} 23$ & $\mathrm{C} 24$ & $\mathrm{C} 25$ & $\mathrm{C} 26$ & $\mathrm{C} 27$ & $\mathrm{C} 28$ & $\mathrm{C} 29$ & C30 & C31 & $\mathrm{C} 32$ & C33 & Total \\
\hline 1985 & 0.70 & 0.80 & 0.51 & 0.81 & 0.50 & 0.64 & 0.70 & 0.83 & 0.73 & 0.54 & 0.55 & 0.55 \\
\hline 1986 & 0.70 & 0.79 & 0.50 & 0.80 & 0.52 & 0.67 & 0.71 & 0.86 & 0.74 & 0.49 & 0.55 & 0.54 \\
\hline 1987 & 0.71 & 0.80 & 0.47 & 0.79 & 0.51 & 0.67 & 0.71 & 0.85 & 0.73 & 0.50 & 0.55 & 0.55 \\
\hline 1988 & 0.70 & 0.81 & 0.46 & 0.80 & 0.51 & 0.68 & 0.69 & 0.86 & 0.73 & 0.59 & 0.61 & 0.55 \\
\hline 1989 & 0.70 & 0.82 & 0.46 & 0.83 & 0.54 & 0.68 & 0.67 & 0.85 & 0.76 & 0.51 & 0.61 & 0.55 \\
\hline 1990 & 0.70 & 0.81 & 0.46 & 0.83 & 0.54 & 0.69 & 0.69 & 0.85 & 0.79 & 0.47 & 0.66 & 0.55 \\
\hline 1991 & 0.72 & 0.82 & 0.49 & 0.84 & 0.55 & 0.69 & 0.71 & 0.85 & 0.80 & 0.44 & 0.65 & 0.55 \\
\hline 1992 & 0.72 & 0.82 & 0.48 & 0.85 & 0.53 & 0.71 & 0.75 & 0.85 & 0.83 & 0.48 & 0.64 & 0.54 \\
\hline 1993 & 0.71 & 0.83 & 0.48 & 0.86 & 0.49 & 0.71 & 0.76 & 0.85 & 0.83 & 0.47 & 0.62 & 0.53 \\
\hline 1994 & 0.71 & 0.82 & 0.49 & 0.88 & 0.51 & 0.71 & 0.75 & 0.86 & 0.85 & 0.48 & 0.61 & 0.54 \\
\hline 1995 & 0.72 & 0.80 & 0.47 & 0.89 & 0.51 & 0.73 & 0.74 & 0.85 & 0.86 & 0.44 & 0.63 & 0.55 \\
\hline 1996 & 0.72 & 0.80 & 0.44 & 0.88 & 0.53 & 0.74 & 0.74 & 0.85 & 0.85 & 0.42 & 0.59 & 0.54 \\
\hline 1997 & 0.72 & 0.80 & 0.43 & 0.87 & 0.55 & 0.75 & 0.75 & 0.84 & 0.86 & 0.44 & 0.56 & 0.55 \\
\hline 1998 & 0.72 & 0.82 & 0.47 & 0.87 & 0.55 & 0.77 & 0.78 & 0.84 & 0.87 & 0.44 & 0.52 & 0.56 \\
\hline
\end{tabular}




\begin{tabular}{lllllllllllll}
\hline 1999 & 0.72 & 0.80 & 0.44 & 0.88 & 0.56 & 0.75 & 0.75 & 0.84 & 0.86 & 0.41 & 0.49 & 0.59 \\
2000 & 0.74 & 0.80 & 0.44 & 0.89 & 0.56 & 0.73 & 0.74 & 0.85 & 0.85 & 0.44 & 0.49 & 0.61 \\
2001 & 0.74 & 0.80 & 0.44 & 0.88 & 0.54 & 0.72 & 0.74 & 0.87 & 0.86 & 0.45 & 0.43 & 0.60 \\
2002 & 0.71 & 0.80 & 0.44 & 0.89 & 0.51 & 0.72 & 0.74 & 0.87 & 0.86 & 0.45 & 0.45 & 0.61 \\
2003 & 0.70 & 0.81 & 0.45 & 0.89 & 0.51 & 0.74 & 0.72 & 0.86 & 0.86 & 0.45 & 0.39 & 0.62 \\
2004 & 0.71 & 0.81 & 0.46 & 0.90 & 0.51 & 0.76 & 0.71 & 0.86 & 0.85 & 0.46 & 0.37 & 0.64 \\
2005 & 0.70 & 0.82 & 0.47 & 0.90 & 0.51 & 0.76 & 0.72 & 0.85 & 0.85 & 0.47 & 0.36 & 0.64 \\
2006 & 0.71 & 0.80 & 0.47 & 0.90 & 0.53 & 0.75 & 0.73 & 0.85 & 0.85 & 0.49 & 0.39 & 0.64 \\
2007 & 0.72 & 0.81 & 0.50 & 0.91 & 0.55 & 0.72 & 0.73 & 0.85 & 0.86 & 0.49 & 0.39 & 0.64 \\
2008 & 0.73 & 0.82 & 0.53 & 0.92 & 0.52 & 0.73 & 0.73 & 0.85 & 0.85 & 0.47 & 0.42 & 0.64 \\
2009 & 0.73 & 0.81 & 0.51 & 0.92 & 0.51 & 0.71 & 0.76 & 0.86 & 0.85 & 0.46 & 0.42 & 0.65 \\
2010 & 0.73 & 0.82 & 0.49 & 0.93 & 0.48 & 0.71 & 0.74 & 0.85 & 0.85 & 0.50 & 0.40 & 0.66 \\
2011 & 0.75 & 0.83 & 0.52 & 0.93 & 0.49 & 0.72 & 0.73 & 0.85 & 0.85 & 0.53 & 0.41 & 0.67 \\
2012 & 0.74 & 0.82 & 0.52 & 0.94 & 0.51 & 0.71 & 0.75 & 0.85 & 0.87 & 0.56 & 0.42 & 0.67 \\
2013 & 0.73 & 0.81 & 0.52 & 0.94 & 0.50 & 0.69 & 0.75 & 0.85 & 0.87 & 0.57 & 0.46 & 0.68 \\
\hline
\end{tabular}

Table 3. Share of top five or ten trade partners

\begin{tabular}{ccccccccc}
\hline & 1975 & 1980 & 1985 & 1990 & 1995 & 2000 & 2005 & 2009 \\
\hline EX 5 & 0.695 & 0.566 & 0.636 & 0.633 & 0.538 & 0.554 & 0.535 & 0.497 \\
EX 10 & 0.794 & 0.697 & 0.771 & 0.753 & 0.689 & 0.689 & 0.650 & 0.622 \\
IM 5 & 0.781 & 0.749 & 0.587 & 0.650 & 0.614 & 0.558 & 0.559 & 0.509 \\
IM 10 & 0.889 & 0.869 & 0.704 & 0.763 & 0.732 & 0.709 & 0.715 & 0.673 \\
\hline
\end{tabular}

* EX indicates that Korea exports to these countries and IM means Korea's import from these countries.

Table 4. Hirschman Herfindahl index for trading partners

\begin{tabular}{cccccccccc}
\hline & 1975 & 1980 & 1985 & 1990 & 1995 & 2000 & 2005 & 2009 \\
\hline EX & 0.171 & 0.105 & 0.161 & 0.139 & 0.079 & 0.086 & 0.085 & 0.077 \\
IM & 0.196 & 0.151 & 0.115 & 0.142 & 0.124 & 0.092 & 0.086 & 0.073 \\
\hline
\end{tabular}

\section{Copyrights}

Copyright for this article is retained by the author(s), with first publication rights granted to the journal.

This is an open-access article distributed under the terms and conditions of the Creative Commons Attribution license (http://creativecommons.org/licenses/by/3.0/). 